\title{
The Use of Identity Card to Improve Students' Speaking Skill
}

\author{
Indah Werdiningsih \& Bagus Yuda Prawira \\ Universitas Muhammadiyah Jember \\ (indah_andin@unmuhjember.ac.id)
}

\begin{abstract}
The study aimes to describe how a communicative activity through the use of identity card influences speaking skills of junior high schools students in Bondowoso. Classroom Action Research (CAR) was implemented using a model by Elliot to the first graders; 10 males and 15 females. It was done in two cycles; each of which consisted of two meetings. The researcher used collaborative action research with some of the English teachers. The data collection involved Test of Speaking English and Speaking Rubric which evaluated fluency, pronunciation, vocabulary, and grammar. The finding showed the mean score of pretest reached 67.8 and that of posttest reached up to 70.2 , resulting in a significant improvement of $42 \%$ in posttest 1 and $64 \%$ in posttest 2 . Therefore, the criteria of success was achieved, indicated by the improvement of students' active participation, confidence and their fluency positively in speaking in peer-interaction and discussion through the contents of Identity Card before practicing in front of the class. Hereby proposed some suggestions addressed to teachers and other researchers who wish to pursue related topics in future research, concerning the importance of communicative activities using Identity Card that can improve students' enthusiasm and motivation.
\end{abstract}

Keywords: speaking skill, communicative activities, identity card

Speaking skill is a crucial part of the language learning process. The teaching of speaking skill is also important due to the large number of students who want to study English in order to be able to use English for communicative purposes. This is apparent in Richards and Renandya's (2002, p. 201) publication where they state that a large percentage of the world's language learners study English in order to develop proficiency in speaking. However, spoken language production or learning to talk in foreign language is often considered to be one of the most difficult aspects in language learning because students must be able to use the language appropriately in their social interactions. Speaking is considered to be the most complex skill since it involves a lot of practice. The students need to apply the English language in real communication. Students should be given opportunity to practice speaking at least when they are communicating with others during the process of teaching and learning. Based on the observation and interview with an English teacher from SMP N 1 Grujugan, the students' speaking skill in the first grade (VII C) is still low. Major problems of the students are poor grammatical structure, poor self-confident, and lack of vocabulary, which are caused by the lack of practice. The average speaking score is 60 in which the minimum score set by the school is $\geq 70$. Most of the students still have problem in organizing and expressing their ideas. They were also still afraid of making mistakes because of the difficulties in 
pronouncing English words and organizing the structure. The expected score is 70 and by the pre-test the researcher found that the percentage of students who got score $\geq 70$ is only $40 \%$ ( 11 students) and the average speaking score 65.00 .

Communicative activities may refer to the spontaneous interaction between teachers and students or among students themselves with the use of appropriate materials, communicative topics, or automatic question-response based on instant thinking and feeling or creativity. Rhalmi (2010) explains that communicative activities have "real purposes such as finding and exchanging information, breaking down barriers, talking about oneself, and learning about culture." It is supported by Richard (2006, p. 17) who state that Communicative activities require students to use their language resources to overcome an information gap or solve a problem. The researcher uses communicative activities through identity card. Klipple (1992, p.13) states the example of communicative activities are trademark, name circle, Identity Cards, choosing pictures, etc. Identity card has aims in speaking skill to question about personal data, introducing someone else to the group and getting to know each other. Klipple (1992, p. 4) says that when the students have to work together in a group it is advisable that they get to know each other a little at the beginning.

\section{Method}

Classroom Classroom action research is chosen to improve the quality of teaching and learning process in the classroom. The primary reason for engaging in action research is to assist the "actor" in improving and/or refining his or her actions" (Sagor, 2000). The participants of the study were the English teacher and 25 students from the first grade of SMP N 1 Grujugan Bondowoso. Based on these considerations, in this study, the researcher used collaborative action research in which she cooperated with one of the English teachers
SMP N 1 Grujugan. The teacher acted as an observer while the researcher acted as teacher who taught by using communicative activities through Identity Cards. The actions of the research are implemented in four stages based on the model of Elliot (1991, p. 70) in which each cycle covers four stages of activities: the planning of the action, the implementation of the action, classroom observation, and the reflection of the action.

After implementing the classroom action research in the first grade students of Junior High Schools, the writer conducted the test (posttest 1 and 2) in each cycle. To compare the test result between pretest and the tests of each cycle, the writer calculating the students mean score of the test, calculating the class percentage, and calculating the students' improvement score from pretest to posttest 1 and posttest 2 into percentage. The interview towards the English teacher was also carried out to know her response about implementation of the action.

\section{The Steps to Apply Communicative Activities through Identity Card}

Since foreign language teaching should help students achieve some kind of communicative skill in the foreign language, all situations in which real communication occurs naturally have to be taken advantage of and many more suitable ones have to be created. Klippel (1992, p. 4) says that when the students have to work together in a group it is advisable that they get to know each other a little at the beginning. Once they have talked to each other in an introductory exercise they will be less reluctant to cooperate in further activities.

Procedure in using the Identity Card for students is as follows.

Step 1: The students are grouped in pairs and each of them receives a blank identity card.

Step 2: the two students in each pair interview each other in order to fill in blanks on the identity card.

Step 3: each student introduce his/her partner to the class using the identity as a memory aid. 


\section{Variation}

1. The paired interviews can be conducted without identity cards. Each student must find out those things from his partner which he thinks are important or interesting.

2. The task 'Find out five things about your partner, that one could not learn just by looking can be given before the interviewing starts.

3. Each student draws a portrait on the identity card. All the cards are exhibited on the classroom wall.

4. If these interviews are done at the beginning of a course or seminar a question about individual expectations can be added.

5. With a very simple identity card this activity is suitable for beginners as well. An appropriate card might look like this.

Example:

\begin{tabular}{|l|l|}
\hline name: & \multirow{2}{*}{ three Rings I like: } \\
\hline tamily: & \\
\hline hobbies: & \multirow{2}{*}{ three things I dont like: } \\
\hline something rd like to do: & \\
& \\
\hline
\end{tabular}

Adapted from, Klippel (1992:16)

\section{Results and Discussion}

The Description of Action in Cycle I

The first step in doing action research was planning the action. The researcher and the English teacher discuss the best way to implement and to use Identity Card in teaching speaking to the first grade students of VII C class. The researchers also decided about the material that would be given to the students. The researcher prepared two lesson plans for the teaching learning process in cycle I based on the curriculum of 2013, the first lesson plan for meeting 1 and the second lesson plan for meeting 2 . The time allocation was 80 minutes for each meeting. The implementation in meeting 1 and 2 were based on the second lesson plan that had been made by the researcher. Here the researcher used Greeting, Parting and introduction as the material, then provided examples of dialogue together with some questions to be filled in the Identity Card for each pairs of students dealing with the speaking skill practices. Afterward the researcher continued teaching speaking based on the procedure of filling the Identity Card and practicing the dialogue. Different samples of dialogues are used for meeting 1 and meeting 2 .

The researcher carried out the observation to control the activities concerning with the application of communicative activities through identity card in teaching speaking. Checklist paper is used to record the students' activities in the classroom and focus on the indicators of the performance of the students in teaching learning process. Table 1 presents the observation result in Cycle 1.

Based on the calculation of the observation checklist result, only $42 \%$ of 25 students were actively participated in the use of Identity Card in teaching learning process. In meeting 1 , the students only active in one of the indicators of observation checklist, some students still afraid to perform the task in front of the class. However, the students were paying attention to the lesson. In meeting 2 , the students were active in two indicators of observation checklist. Most of them were paying attention to the lesson and performing the task. It means that the requirement of $50 \%$ of the students' active involvement in the teaching learning process of speaking ability was not yet fulfilled which means that the students did not give optimum response.

The reflection was done after calculating the students' score of speaking test. The mean score was 67.8 and the percentage of students who got score $\geq 70$ was $60 \%$ as provided in Table 2 .

As mentioned before, the cycle of this research was considered to be successful if the score of the students' speaking test had reached 
Table 1. The Average of Observation Checklist

\begin{tabular}{ll}
\hline \multicolumn{1}{c}{ Meeting } & \multicolumn{1}{c}{ Active } \\
\hline Meeting 1 & $(10 / 25) \times 100 \%=40 \%$ \\
Meeting 2 & $(11 / 25) \times 100 \%=40 \%$ \\
\hline Total & $84 \%$ \\
\hline Average & $42 \%$ \\
\hline
\end{tabular}

Table 2. The results of speaking test cycle 1

\begin{tabular}{lcc}
\hline \multicolumn{1}{c}{ The Data Results } & Total & Percentage \\
\hline $\begin{array}{l}\text { The students who get } \\
\text { score } \geq 70\end{array}$ & 15 & $60 \%$ \\
$\begin{array}{l}\text { The students who get } \\
\text { score } \leq 70\end{array}$ & 10 & $40 \%$ \\
$\begin{array}{l}\text { The average of all stu- } \\
\text { dents }\end{array}$ & 67.8 \\
\hline
\end{tabular}

70 or more and it was achieved by at least $75 \%$ of the total students. From the result, it can be concluded that the standard score requirement of the students in speaking subject was not achieved yet. Even so, there are some significant improvements of the speaking aspects and we can already see an improvement of the test result from $44 \%$ in students' pretest score up to $60 \%$ in Cycle 1 test.
Table 3. The results of speaking test cycle 2

\begin{tabular}{lcc}
\hline \multicolumn{1}{c}{ The Data Results } & Total & Percentage \\
\hline $\begin{array}{l}\text { The students who get } \\
\text { score } \geq 70\end{array}$ & 20 & $80 \%$ \\
$\begin{array}{l}\text { The students who get } \\
\text { score } \leq 70\end{array}$ & 5 & $20 \%$ \\
$\begin{array}{l}\text { The average of all stu- } \\
\text { dents }\end{array}$ & 70.2 \\
\hline
\end{tabular}

The Description of Action in Cycle 2

The action In Cycle 2 were conducted in two meetings, the researcher focused more on the interaction between the researcher and the students, and dicussed the material through the contents of Identity Card before the students practice in front of the class. In meeting 1, three indicators of observation checklist were achieved. The students were quite active asking and answering questions, but some students still did not understand the topic well. The researcher asked the student to disscuss with their partners and prepared a dialogue based on the contents of Identity card. In meeting 2 , most of them were paying attention to the lesson and performing the task, the students were enthusiastic to join the

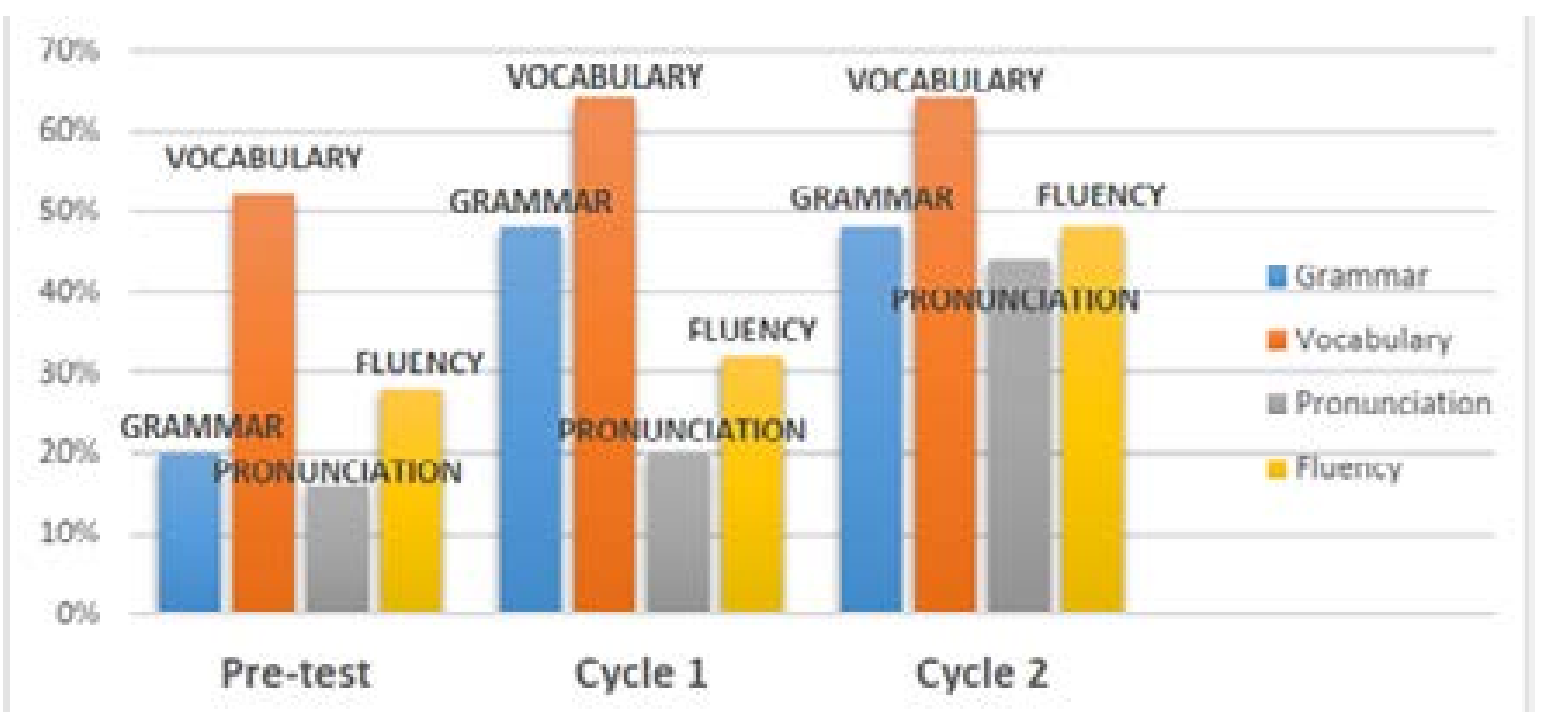

Figure 1. The improvement of speaking aspect from cycle 1 to cycle 2 
lesson and focused to perform and practice using English.

The observation result of students' involvement in meeting 1 and 2 in Cycle 2 showed that $64 \%$ of 25 students were actively participated in the teaching and learning process. In brief, there was $22 \%$ of improvement in the students' participation in Cycle 2. The students gave optimum response, and most of them were actively participated in teaching and learning process.

After conducting two meetings in Cycle 2 , the researcher gave a test to the students. The reflection was done after calculating the students' score of speaking test.

Based on the result of speaking test in Cycle 2, the mean score was 70.2 and the percentage of the students who got $\geq 70$ was $80 \%$. There were 20 students who got $\geq 70$ in speaking test and 5 students less than 70 .

Students' speaking score improved from $60 \%$ in Cycle 1 up to $80 \%$ in Cycle 2. It means that the targeted score requirement in this research had already been achieved.

Overall, in Cycle 1, the problems faced by most of the students are fluency and pronunciation. In order to fix this, the researcher drilled them by doing repetition and imitation. The researcher guided the students to discuss the material through the contents of Identity Card before the students practice in front of the class.

\section{Conclusions}

Based on the result and discussion during the Cycle 1 up to Cycle 2, the use Communicative Activities through Identity Card could improve the students' speaking ability in teaching learning process. The students made considerable improvements on their speaking skill. In conclusion, the use of Identity Card is able to improve the speaking skill by encouraging the interaction and discussion among students, it could also help them to speak English fluently, accurately on pronunciation, vocabulary and grammar and it is worth to be carried out for the next speaking class. The action in Cycle 2 can be stopped.

\section{References}

Akhyak \& Indramawan, A. (2013). Improving the Students' English Speaking Competence through Storytelling. International Journal of Language and Literature, Vol. 1 (2), 18-24

Arikunto, S. (2010). Penelitian Tindakan Kelas. Jakarta : Rhineka Cipta.

Bashir, M., Azeem, M. \& Dogar, A. H. (2011). Factor Effecting Students' English Speaking Skills. British Journal of Arts and Social Sciences. Vol.2 (1), 34-50

Brown, H. D. 2001. Teaching by Principles, an Interactive Approach to Langugae Pedagogy (2nd Ed.). New York: Pearson Education.

Brown, H. D. 2004. Language Assessment: Principles and Classroom Practices. New York: Pearson Education, Inc.

Cameron, L. 2001. Teaching Language to Young Learners. Cambridge: Cambridge University Press.

Elliot, J. 1991. Action Research for Educational Change. Ballmoor: Open University Press.

Fitria, S. 2013. Speaking Activities In Young Learners Classroom: the Implementation of Project-Based Learning Approach. Journal of English and Education, Vol 1 (2), 90-102.

Grant. N. 1987. Making the Most of Your Textbooks. Hongkong: Longman

Gudu, B. O. 2015. Teaching Speaking Skills in English Language Using Classroom 
Activities in Secondary School Level in Eldoret Municipality, Kenya. Journal of Education and Practice. Vol 6 (35), 55-63

Hughes, R. 1989. Spoken English, TESOL and Applied Linguistics Challenges for Theory and Practice, University of Nottingham.

Khan, N. \& Ali, A. 2010. Improving the Speaking Ability in English: The Students' Perspective. Procedia Social and Behavioral Sciences Vol 2, 35753579

Klippel, F. 1992. Communicative Fluency Activities for Language Teaching, United States of America: Cambridge University Press.

Littlewood, W.T. 1981. Communicative Language Teaching: An Introduction. New York: Cambridge University Press.

Moss, D. \& Ross-Feldman, L. 2003. Activities to Promote Interaction and Communication. (Online), http://www.cal.org/caela/tools/ program_development/elltoolkit/ Part241Interaction\&Communication. pdf

Oradee, T. 2012. Developing Speaking Skills Using Three Communicative Activities (Discussion, Problem-Solving, and Role Playing). International Journal of Social Science and Humanity. Vol 2 (6), 533535

Ramos, I. D. D. 2014. Communicative Activities: Issues on Pre, During, and Post Challenges In South Korea's English Education. International Journal of Education Learning and Development. Vol.2 (1), 1-16.

Rhalmi, M. 2010. Communicative Activities. Retrieved February 8, 2014,(Online), (http://www.myenglishpages.com/blog/ communicative-activities)
Richard, J.C. 2006. Communicative Language Teaching Today. Cambridge: Cambridge University Press.

Richard, J.C. 2008. Teaching Listening and Speaking: from Theory to Practice. Cambridge: Cambridge University Press.

Thornbury, S. 2005. How to Teach Speaking. Harlow: Pearson Education Ltd. 